\title{
Faculty Note
}

\section{A Postscript to the Miranda Project:}

\section{Interrogation of Draft Protestors}

The suspect . . . is in a crisis-laden situation. The stakes for him are high-often his freedom for a few or many years-and his prospects hinge on decisions that must be quickly made . . . Unless he is a professional, the suspect is unlikely to know the movements of the law enforcement machinery. The likely consequences of the alternatives open to him are unclear....

In such a thicket, the Miranda warnings are no substitute for the close knowledge of the institutions and personalities of the criminal process that the suspect will never have.

The above quotation from "Interrogations in New Haven: The Impact of Miranda"1 expresses one of the main conclusions of the Journal's empirical study of police interrogations. The ellipses contain references to the typical criminal suspect's situation. This "Postscript" examines the applicability of the Miranda Project's generalizations to a completely different sort of suspect: one who committed his "crime" openly and willfully, as an act of civil disobedience. Its value lies, we think, in the fact that our conclusions parallel those of the Miranda Project.

\section{Background}

During the week beginning Monday, October 23, agents ${ }^{2}$ of the Federal Bureau of Investigation questioned about 21 undergraduate and graduate students, faculty, and staff of Yale who had earlier turned in their draft cards [hereafter we refer to those who were contacted as "suspects," for simplicity's sake]. ${ }^{3}$ Struck by the way familiar problems of making constitutional rights effective in the interrogation process

1. 76 Yale L.J. 1519, 1613-14 (1967), [hereinafter cited as Project].

2. Some 10 agents were apparently involved.

3. We worked closely with these people, informing them of their rights and discussing the possible consequences of the courses of action open to them. The 21 suspects do not include 12 Divinity School students who responded to a written request by the FB1 for interviews, but refused to answer any questions. 
arose even in this unusual context, we interviewed in detail all those who had been contacted or interrogated by the FBI. This Note is a report of our findings.

Briefly, the events at Yale were as follows: There appears to be growing opposition to the war in Viet Nam among students and faculty. The movement known as "The Resistance," together with parallel groups, has been growing; it consists of people who refuse further cooperation with the draft and the war effort and symbolically return their draft cards to the Government. On Friday, October 20, a group of several hundred, including the Yale University Chaplain and several Yale professors, deposited nearly 1000 draft cards at the Justice Department in Washington. These included about 50 cards from Yale, of which about 25 were collected from present Divinity School students and two former students of the School, following a service at the Divinity School.

All this is by way of context. The one additional point that requires emphasis is how disorganized the Yale antiwar movement was prior to the FBI's visit. No one involved in the draft-card return campaign seems to have addressed any advance thought even to elementary legal questions. ${ }^{4}$ In particular, there was no advance planning for legal repre-

4. The following are some of the kinds of problems which almost no one seems to have considered:

(1) What sorts of issues could be raised as defenses to a charge of nonpossession, as contrasted with other possible charges (e.g., refusal to submit to induction), and what sort of proceeding would best produce the desired moral confrontation with the govemment?

(2) What defense strategies would be appropriate to the nature of the protest-insisting upon guilt? carrying "resistance" into the courts by refusing to cooperate in the process of conviction? challenging the validity of the possession requirement on a variety of statutory and constitutional grounds? It should be noted that the statute, Universal Arilitary Training and Service Act, 62 Stat. 604 (1948), as amended, 50 US.C. app., $\$ \$ 451-73$ (1964), does not require possession of draft cards. This requirement is contained in 32 C.F.R. $\$ \S 1617.1,1623.5$ (1967). The following questions are unresolved: Is the Regulation authorized by the statute, and should the statute be narrowly construcd to avoid potential constitutional problems of excess delegation, sclf-incrimination, and undue deprivation of liberty? should the Regulation be narrowly construed to apply only in circumstances in which possession is relevant to the registrant's duties under the Selective Service Law? See Kent v. Dulles, 357 U.S. 116 (1958).

(3) What possibility might there be of piecemeal prosecutions, and is it possible to do anything to avoid or prevent this? For example, Rule 5 of the Federal Rules of Criminal Procedure clearly contemplates civil arrests, and it may be that piccemeal prosecutions could be forestalled if the offenders undertook to arrest each other, filing strom complaints based upon attached, sworn confessions.

(4) Might some sanction other than prosecution-e.g., reclassification as "delinquent," or a Congressional investigation-be used by the government, and if so, how should it be met? Three of the Yale suspects have already been reclassified 1-A. Two of these were Divinity School students who had 4-D classifications and were among the suspects questioned on Monday who gave very full statements to the FBI. They also share a common draft board. On November 8 and 9, the New York Times reported that General Hershey (after consultation with the White House, he said) had issued a letter to the personnel of the Selective Service System (dated October 26), and a Local Board Mremorandum (No. 85, Oct. 24, 1967), both of which "recommended" that local boards reclassify as delinquent, among others, any registrant whose "abandoned or multilated registration certifi- 
sentation and counselling, and no anticipation of the possibility of an FBI investigation. Therefore when FBI agents arrived on the campus Monday morning, virtually no one had thought much about whether he should say anything, or what he would say, if interrogated. No information had been disseminated on the rights of persons to refuse to answer questions and to consult with a lawyer before making a decision whether and what to answer. No one had explained to the potential suspects why they might want not to speak and what the various considerations might be. No thought had been addressed to connections between the theory of their protest and what their reaction should be to an investigation. Finally, no common decisions had been made on how to react to the $\mathrm{FBI}$, or whether such a common front would be desirable.

On Monday morning, October 23, shortly after 9 o'clock, Dean Johnson of the Diyinity School learned that FBI agents intended to question Divinity School students who had turned in their cards. The interrogations began immediately thereafter. That day five Divinity School students and the Assistant to the University Chaplain were interrogated. Word spread quickly, and several persons telephoned the Law School for legal advice immediately before or after being questioned. A number of us at the Law School concluded almost at once that something should be done to inform those about to be interviewed of their rights and to help them obtain a lawyer if they felt the need. Twelve members of the faculty drafted a letter to the Chairman of the Yale Daily News, which was published the next day. ${ }^{5}$ Notices giving warning

cate or current notice of classification" it receives, on the ground of "failure to have the card in his possession." N.Y. Times, Nov. 8, 1967, at 1, col. 1, 7, col. 1 ; Nov. 9, 1967, at 2, col. 3, 3, col. 1. See also Nov. 11, 1967, at 5, col. 1 .

At least one Congressional investigation is getting under way, by the Senate Internal Security Subcommittee, aimed at "organizations of the New Left, including militant civil rights and antiwar groups." N.Y. Times, Oct. 26, 1967, at 1 , col. 8. The plans for this investigation were disclosed on Thursday of the week in which the FBI interrogations at Yale took place.

5. Its text is as follows:

To the Chairman of the NEWS:

We understand that agents of the FBI have been on the campus interrogating Yale students who turned in their draft cards. Students should know that they are under no obligation to say anything at all to an FBI agent, and that they should consult with a lawyer before deciding whether to make a statement. Information on the availability of legal advice can be obtained by phoning Dwight Hall, extension 2116 or extension 2117.

\author{
Ralph S. Brown, Jr. \\ Guido Calabresi \\ Marvin Chirclstein \\ Steven Duke \\ Ronald M. Dworkin \\ Abraham S. Goldstein
}


of the FBI's presence and emphasizing the right to silence were posted all over the campus. A meeting was organized for that evening. Professors Summers, Reich and Griffiths spoke on the legal rights of persons being questioned. They explained some of the working of the criminal process, clarifying the possible uses to which information gathered by the FBI might be put. They discussed the possible objectives of the questioning, the functions a lawyer could perform for a person trying to decide whether and what to answer, and the necessity that a person decide what his goals are before seeking legal advice as to how to accomplish them. Those present were told that they could phone a designated extension to obtain the numbers of local ACLU lawyers who would be willing to represent them. Questions of strategy were then debated at some length, and the sense of the meeting became clear that talking to the FBI could serve no useful purpose and might conceivably be harmful. Dean Johnson of the Divinity School requested that his students ask agents to report to his office. ${ }^{\circ}$

On Tuesday, 11 more people were interrogated. The Yale Daily News carried both the letter from Law School faculty members and an article on Monday's events. A New Haven newspaper also carried a story. Dean Johnson posted a notice asserting that "the presence of several FBI agents on the Divinity School campus Monday, was disruptive of the orderly process of the school." He announced that, "as of October 24, no agent of the FBI has permission of the Dean to be on Divinity School property for the purpose of interviewing students." 7

On Wednesday, the FBI interrogated two suspects. Thursday and Friday two more interrogations took place. There was further coverage of the issue in the Daily News. On Friday, the Secretary of the Univer-

Joseph Goldstein
John Griffiths
Louis H. Pollak
Charles. A. Reich
Clyde W. Summers
Harry H. Wellington
Members of Faculty, Yale Law Scliool.

Yale Daily News, Oct. 24, 1967, at 2, col. 3.

6. Two students later told Dean Johnson that they had convejed his request, but the agents refused to report to him and continued their interrogations.

7. Yale Daily News, Oct. 25, 1967, at 1, col. 3. Although the FBI agents took the position that they were entitled to interrogate on campus, they apparently did not do so after learning of Dean Johnson's position. The master of one Yale college was reported as having denied the FBI permission to interrogate a student at his college "without my previous consent." Another master saw "no reason or value in answering the FBI questions." Both of them requested that interrogations be conducted in their offices or in the presence of the college dean or master. A third master-also a professor of law- offered his legal advice to students who wanted to understand the possible consequences of interrogation. Id. 
sity sent letters to those Divinity School students who had not yet been interrogated, requesting that the students make an appointment to come to FBI headquarters the following Monday, and stating that, "Should you not appear, the FBI will have to interview you elsewhere." A personal letter to each student from Dean Johnson was enclosed ${ }^{0}$ together with the advice-waiver-of-rights form the agents had given other suspects when they questioned them. ${ }^{10}$ Most of those who had received the letter went to FBI headquarters on Monday. On the same day the FBI stated that it had "no further instructions," and the interrogations of people at Yale came to an end.11

8. The letter, on blank paper and undated, was as follows:

Dear Mr. —:

The FBI would like to interview you any time between 8:30 and 5 P.M., on Mon. day, October 30, and will do so in the Bureau's Offices at 205 Church Strect, in order to avoid disrupting academic activities on the campus.

Enclosed is a list of your rights which the Bureau will inform you of prior to being interviewed. The Dean is aware of this procedure.

Should you not appear, the FBI will have to interview you elscwherc. If Monday is not convenient, please telephone the FBI Office $(787.1217)$ for another appointment.

9. This letter read as follows:

Office of the Secretary.

If you have any questions about this, please see Mr. Noyce [Dean of Students of the Divinity School], Mr. Adams [Associate Dean of the Divinity School], or me.

If you do not intend to exercise your right to remain silent, and wish us to atssist you in making arrangements to talk with a lawyer, we will be glad to do so.

10. The advice-waiver form read as follows: /s/ Robert C. Johnson, Dean.

\section{YOUR RIGHTS}

PLACE

DATE

TIME

Before we ask you any questions, you must understand your rights.

You have the right to remain silent.

Anything you say can be used against you in court.

You have the right to talk to a lawyer for advice before we ask you any questions and to have him with you during questioning.

If you cannot afford a lawyer, one will be appointed for you before any questioning if you wish.

If you decide to answer questions now without a lawyer present, you will still have the right to stop answering at any time until you talk to a lawyer.

WAIVER OF RIGHTS

I have read this statement of my rights and $I$ understand what my rights arc. I am willing to make a statement and answer questions. I do not want a lawycr at this time. I understand and know what I am doing. No promises or threats have been made to me and no pressure or coercion of any kind has been used against ine.

Witness

Witness

11. Yale Daily News, Oct. 31, 1967, at 1, col. 7. It should be noted that the above account of the numbers of people interrogated each day is based upon those who came to our attention in various ways and whom we interviewed. We may well have misscd some.

$$
\text { Signed. }
$$

$$
\text { Time }
$$

\section{4}




\section{How We Conducted the Interviews}

On Wednesday we decided to interview those who had been interrogated. We drew up a set of questions, ${ }^{12}$ and, armed with tape record. ers, undertook to interview every person who, to our knowledge, had been contacted for questioning by the FBI. We held all interviews but one on Thursday and Friday, within five days of the interrogations at most, and in most cases much less. We did not interview those who responded to the FBI letter, since their cases did not seem to have enough in common with the others to make such additional interview- . ing worthwhile. ${ }^{13}$ The interviews each lasted about half an hour. We were extremely impressed by the care and precision with which our subjects reconstructed their respective interrogations.

\section{Who the Suspects Were}

Of the 21 people we interviewed, seven were members of the Yale faculty or staff, 11 were graduate or professional students, and only three were undergraduates. The oldest was 36 and the youngest 19; their average age was 25. A substantial minority of them were old enough, or enough encumbered with family obligations, to be virtually draft exempt. One had actually received an honorable discharge from the Army, along with a letter of commendation from his commanding officer. Ten held advanced degrees, and several held more than one.

All were eligible for at least temporary draft deferment. Many had or could have availed themselves of the 2-S deferment as students; the divinity students were eligible for a special exemption and would be permanently exempt when they became ministers. Several of those questioned were already ordained ministers, and five were professors.

In spite of their superior education, few of the suspects knew their

12. These were designed to elicit the following: educational background; details concerning the time and duration of the interrogation; an unassisted narrative account of the interrogation; specific details about the conduct of the interrogation, particularly with respect to the giving of Miranda wamings and the use of "tactice"; whether the suspect had independent knowledge of his rights-in particular, what role the Monday night meeting may have had in influencing his behavior during interrogation; what questions he was asked, what ones he answered, and why; and whether, in the light of subsequent opportunity to think about the significance of his rights, he would have conducted himself differently during the interrogation.

13. We were told by the leader of the group that the following experience was typical: they reported in groups of three or so to FBI headquarters; they were intervicwed one by one; each was asked his name and then given the Mfiranda waiver form; all of them refused to sign the waiver or to answer any questions, except those concerning personal factual details, e.g., age, height, and the like (in one case, additional answers were apparently given to questions concerning the suspect's family background). 
rights in even the grossest outline. Only two mentioned spontaneously having heard of the Miranda or Escobedo decisions, and only one said that the FBI waiver form told him nothing he had not already known before the meeting Monday night. Some said they had understood that they did not have to tell an investigator anything, and a few mentioned knowing they could have a lawyer (though they were vague about when they had this right). Of those who said they had known that anything they said could be used against them, none displayed familiarity with how what he said could be used. It was plain to us that the widesprend publicity given Supreme Court decisions had simply not prepared them to understand and exercise their rights, perhaps because they had never expected to be interrogated as criminal suspects. In the words of one suspect, "It's kind of like knowing what the idea of a centaur is about -or going to jail-you sort of have it in your mind, but you never really appropriate it until it hits you personally. It just doesn't occur to you that you ought to make use of these rights."

\section{How the Interrogations Proceeded}

The interrogations followed a standard format. Two agents arrived at the suspect's home, office or dormitory room. In eight cases their visit was unheralded; in six cases; they had telephoned beforehand; and in seven cases their impending visit was presaged by an earlier unsuccessful attempt. They confirmed the suspect's name, identified themselves, and asked to speak to the suspect alone. Two suspects insisted on having their wives or friends present; the agents successfully discouraged two others who expressed such an interest.

Unless cut off at the outset, the agents came quickly to the point. One asked the questions, while the other recorded the answers with pen and paper. When a statement was taken, the agent asked the student to sign it and to initial any changes he made in the wording. They began by inquiring whether the suspect had his draft card in his possession and, if not, where it was. They then wanted to know whether he had turned in his card, and under what circumstances. Finally, they asked why he had done so, and who had influenced him to take his action. Interspersed with these questions came small talk and questions about biographical data such as his age, height, weight, and identifying marks. If rebuffed on the more important questions, the agents retreated to the apparently harmless biographical questions to keep the conversation going. When they obtained written statements, they did 
not volunteer to give the suspects copies; only the most insistent suspects obtained them.

On Monday the agents obtained answers to most of their questions, so that the interrogations lasted an average of an hour. Later, when they were less successful, the interviews took about 10 minutes.

\section{Advice of Rights by the FBI ${ }^{14}$}

Unlike the New Haven detectives, the FBI agents advised virtually every suspect of his rights. ${ }^{15}$ This was accomplished with a form similar to that developed by the New Haven police within three months of the Miranda decision. ${ }^{16}$ Of the 21 suspects, only two were given no warning at all, $\mathbf{1 7}$ and only one was given an inadequate warning. On the other hand, more than half of the suspects were not given the form or otherwise warned until after the agents had asked whether they had their

14. The FBI acted throughout this episode on the assumption that the rules governing interrogations set forth in Miranda v. Arizona, 384 U.S. 436 (1960), applied. We have made the same assumption, supported by the following considerations: (I) The right to silence and the privilege against self-incrimination clearly apply-the former because there simply is no duty to speak to investigating officers, and the latter because of the possibility of criminal consequences. (2) The rights to have counsel present at interrogation or to consult with counsel prior to making any statement clearly apply, both because the person interrogated has no duty to speak and hence can condition his willingmess as he chooses, and because interrogation of any sort is a "critical stage" at least for purposes of the right to retained counsel. See Escobedo v. Illinois, 378 U.S. 478, 484-492 (1964). (3) The troublesome question is whether the Miranda warnings must be given (and also, although tre are not here concerned with this question, whether denial of the rights to silence or to counsel, or failure to follow the Afiranda rules for effecting those rights, would require exclusion of any statement obtained from a suspect). Mironda itself did not go beyond "custodial" interrogations and asserted that the test of whether police investigation has "begun to focus on a particular suspect," as used in Escobedo, had also referred to a custodial situation. 384 U.S. at 444 n.4. However, the Court in Aliranda had no occasion to address itself specifically to noncustodial interrogations, and the limitation it fixed upon the scope of the new requirements laid down was undoubtedly designed to avoid the morass of almost insoluble problems which would have been raised if the Escobedo formula for distinguishing investigations from interrogations had been used. (Escobedo, it should be recalled, involved denial of the right to counsel, not mere failure to give Miranda-type wamings.) "Custody" was an available bright-line test, serviceable for the cases before the Court, retroactively serviceable for Escobedo, and suitable for most interrogation situations. But there is nothing in Mfiranda which suggests that a case of obvious interrogation, posing the same problems of effective excrcise of the rights to counsel and to silence, and readily distinguishable from mere investigation, viould not also be held to be covered by the Miranda requirements when the occasion presented itself. There is no apparent reason, particularly in light of the findings we report herein, why a decision made solely as a matter of police convenience-where to interrogate and whether to bother with an arrest-should alter the protections afforded to a suspect.

15. Miranda was new to the New Haven detectives when the Journal study was begun, and their record of giving the warnings increased dramatically over the period of observation. With the introduction of the waiver form in New Haven, the detectives may viell have given the full warning to most of the suspects they interrogated. Project 1550-51.

16. Miranda v. Arizona, 384 U.S. 496 (1966). The FBI's form is set forth in note 10 supra.

17. This does not include three persons who announced their unwillingaess to answer questions at the very outset. 
draft cards in their possession. Almost as many were asked other incriminating questions before being advised of their rights. Furthermore, the form which was presented to the suspects to advise them of their Miranda rights followed this advice with a paragraph waiving those rights in the language of Miranda, with a space for the suspect to sign. The suspects were often asked to sign the waiver as the form was presented to them. Thus the nature of the Miranda form, together with the way in which it was presented to the suspects, combined to convey the expectation that the Miranda rights would be waived.

Finally, in most cases the advice-waiver form was simply presented to the suspect, with the terse observation that it stated his constitutional rights. There was no attempt to explain what the significance of those rights might be, or how the abstract statement of rights might apply to the concrete questions the agents were about to ask. In sum, even in these undemanding situations, the FBI's adherence to $M i$ randa's requirement of warnings was grudging at best.

The Miranda Project observed that detectives complied less readily with Miranda's requirement that they halt questioning whenever the suspect "indicates in any manner ... that he wishes to remain silent," than with the requirement to give warnings. ${ }^{18}$ Much the same conclusion emerges with respect to interrogations by the FBI. After Monday, every suspect said clearly that he did not want to answer questions. Yet, without exception, they were forced to repeat their refusal several times before convincing the agent that they were not going to answer. As one suspect commented, "[the interview] lasted quite a while for a conversntion without a content." When satisfied that a suspect would not answer the primary questions about possession of his draft card, whether he had turned it in, and his reasons for having done so, in most cases the agents then sought to obtain personal information of an apparently innocuous sort-height, weight, age, and the like. In almost every case they succeeded in getting this information, even though the suspect had clearly asserted his desire not to answer any questions.

On the whole, except for their persistence the agents accepted refusals to answer in good grace, with an "OK, that's your right." However, there were some more heavy-handed reactions, reminiscent of those of the New Haven police. ${ }^{10}$ Two suspects who refused to answer were told gravely that, "Of course, you realize we will have to report

18. Project 1554-56.

19. Project 1545, passim. 
that you refused to answer questions." One was told threateningly that turning in both his registration and classification cards constituted two offenses, each punishable by five years' imprisonment and $\$ 10,000$ fine. When one suspect requested that the agents return after he had had time to consult a lawyer, he received the irritated reply, "There is a matter of a federal crime here, you know-we can't draw this thing out indefinitely." An agent solemnly warned an ordained minister: "You understand that people in your position are not immune from the consequences of your action." A professor was told, "Most of the people we've seen are like you-clean-cut and serious-and we think you are being terribly misled. You just can't go around breaking the law." Moments later, one of the agents assumed the "heavy" role of the "Mutt and Jeff" routine, reached into his briefcase, appeared to peruse some of the papers inside, and scowled in apparent anger, saying "Especially in your case I would think ...." before being cut off by the "friendly" member of the duo. A suspect who steadfastly refused to answer the question whether he had his draft card was told, "This doesn't concern your right of silence-we just want to see your card." The agent repeated this assertion several times before he became convinced that nothing was to be gained by the tactic. Finally, a minister interviewed late in the week received this entreaty: "We don't understand why people don't want to cooperate now if they're trying to make a point."

The point here, as in the Miranda Project, is not that these tactics will overwhelm someone who forcefully asserts his rights. ${ }^{20}$ The point is that the manner in which FBI agents administered Miranda warnings again reveals the difficulties inherent in the Supreme Court's approach to the problem of evening the balance between the suspect and the interrogator. Even the professionally-spirited agents of the FBI do not always give the warnings when they should, nor can they always restrain themselves from improper reactions to a claim of right. Above all, they cannot be expected to give the warnings in a sympathetic way or to assure full comprehension and appreciation in the suspect. It is hardly realistic to expect an interrogator to have the solicitude for the interests of the suspect which is required if the suspect is to be enabled to appreciate the significance of his rights in the context of what is at stake in the interrogation. To ask a detective, whether from the New Haven Police Department or the FBI, to act both as interrogator and

20. It is possible that they would not be held to be violations of Miranda, although they seem clear violations of the spirit of the decision. 
as counsel for the defense is to require a capacity for schizophrenit as a qualification for the job.

\section{The Effect of Warnings by the FBI}

The Journal's study of of the impact of Miranda in New Haven con" cluded that warnings, even when given clearly and distinctly and without any attempt to discourage the suspect from exercising them, are an inadequate means to assure that he can make an informed decision whether to answer questions..$^{21}$ The observations which led to that conclusion may have derived in part from the trauma of arrest, the "inherently coercive" stationhouse atmosphere, and the apparent inability of many ordinary criminal suspects to understand, or even to read, a printed warning. The suspects in this study-all of them well-educated and highly intelligent, and questioned in their homes or offices without an arrest-enabled us to test the Miranda Project's conclusion in a situation where those other factors were not present. Under these favorable circumstances, it appears that the waiver forms effectively conveyed the limited message that one could remain silent or could ask to see an attorney. Of the five suspects interrogated on Monday, before the meeting at which rights were explained, all but one said they had learned of at least some part of their Miranda rights from the form the agents gave them. Most of the suspects interrogated, before and after the Monday meeting, told us that reading the form reassured them in their as. sertion of their rights. ${ }^{22}$

However, despite the effectiveness of the forms in conveying the literal meaning of the Miranda advice, most of the suspects interrogated on Monday signed the waiver form, and all gave written statements to the agents. ${ }^{23}$ All of these told us that in the light of the explanation of rights afforded after their interrogation by the Monday night meeting, they regretted having answered the agents' questions. It should be em* phasized that this regret was entirely based upon a greater understand-

21. Project 1562-78.

22. The form also stimulated the suspects to think about the significance of their rights. One, for example, raised on his own initiative the question whether he could stop, answering at any time, or answer selectively. He was assured by the agents that he could. Cf. Miranda v. Arizona, 384 U.S. 436, 468 (1966). But cf. Project 1570.79.

23. Four of the five signed their written statements. The fifth gave his statement carly in the morning, and the agents had it typed and brought it back for his signature sevcral hours later. In the interim he had learned that lawyers were advising suspects to refuse to answer questions. In an attempt to recoup his losses, he refused to sign the statement when it was brought to him. The agents then asked if they could say that the statement was the substance of what had been discussed, and he agreed that it was. 
ing of the role of interrogation in the criminal process, the possible uses of admissions in a trial, and the extra-judicial uses of admissions; none of them regretted making the statement simply because, having had some legal advice, they later concluded they might be able to "beat the rap" except for their admissions under interrogation. In other words, we have here a fairly pure case of admissions made simply because of a lack of understanding of the nature and function of the constitutional rights at stake, and of later regret based wholly upon increased understanding, not a change of heart.

The partial effectiveness of the Miranda warnings given the Monday suspects is illustrated by the way in which they answered questions. Most refused to answer one or more questions, though the refusals were in no consistent pattern. ${ }^{24}$ The differences in the questions which different suspects refused to answer illuminate the fundamental point. Even though the suspects understood that they could refuse to answer whenever they chose, they had only the vaguest intuition about how to decide whether to answer a given question. ${ }^{25}$ Their decision whether to waive their right to remain silent was made on hunch alone, without any of the knowledge or understanding required to make it "knowing and intelligent." ${ }^{26}$ Their waiver of the right to a lawyer's advice was even less informed, since their ignorance of the significance of the right to silence was compounded by their ignorance of the functions a lawyer might have performed for them.

\section{The Effect of Knowledge Obtained from a Friendly Source}

The Monday meeting afforded those who were interrogated there-

24. One refused to talk about who might have infuenoed him to turn in his card or to discuss his reasons for turning in his card; two answered a question about who might have influenced them, but refused to give their reasons; two answered both these questions. None actually attributed turning in his card to the infuence of some other person. One engaged in a lengthy philosophical discussion of his reasons. Thus the warnings were to some extent effective in encouraging suspects to act upon the rights recited to them on the paper. Of course, social status and educational background probably account for most of the greater capacity to act on their rights shown by these suspects, in contrast with those interrogated by the New Haven police.

25. One who did not answer the question why he had turned in his card told us he refused because someone had mentioned to him earlier in the day that it might cause some "legal complications" if he did. Another allowed an agent to write in his statement that he had "willfully and deliberately" relinquished his draft card, even though he would have preferred that the statement read "unwillingly and deliberately" because be wanted to convey the idea that he did not want to violate the law, but felt compelled to by his conscience. He twice asked them to change the words, but they replied, "It's merely a legal formality-that's just legal language." The distinction might have been the basis for an argument to a court, but the suspect could not assess the importance of allowing what seemed to be a trivial change in wording.

26. See Johnson v. Zerbst, 304 U.S. 458, 465 (1938); In re Gault, 387 U.S. 1, 42 (1967). 
$\operatorname{after}^{2 \gamma}$ a substantial degree of understanding of the nature and significance of their rights. It corrected a number of misconceptions they had about the interrogation process. The effect of the meeting was dramatic. While all those interrogated before the meeting made more or less full incriminating statements to the agents, no suspect interrogated after the meeting did so. All but two of the 16 refused to say whether they had their draft cards; none answered the questions about whether he had turned it in or who, if anyone, had urged him to do so, although two others made minor admissions. On the whole, then, the suspects were able to put into action the consensus of Monday night that they would not answer the agents and did not answer the major questions answered by suspects on Monday. Thus, given the kind of information imparted by the lawyers during the meeting Monday night, highlyeducated suspects seem able-in a non-custodial interrogation conducted according to Miranda rules-to exercise their constitutional rights fairly effectively, and, even in the absence of a lawyer, to behave as most lawyers would probably have counseled.

Even this optimistic assessment must be qualified. Despite their success in asserting their rights in the light of some comprehension, nearly all the suspects felt obliged to carry out the charade of an interrogation. Most of them invited the agents into their homes, made small talk with them, and gave answers which they felt could not in any way be incriminating-biographical and personal facts. Often the agents sought to distinguish between the real questions they needed answers to, and mere "background" information, as they often called it. Those who were acting out the charade felt somehow obliged to answer questions so put.

VIII. Why the Suspects Felt Impelled to Speak to Interrogators

The question why suspects talk to interrogators is one which has evoked many different answers in the controversy over the Miranda decision. In the early Supreme Court decisions dealing with coerced confessions, the reasons often were simple enough: The confessions sprang from torture and the like. However, as the "voluntariness" fourteenth amendment standard for coerced confessions developed, the

\footnotetext{
27. All but one of those interrogated after Monday had been at the meeting; the one exception learned of the contents of the meeting from friends. We have included in the post-Monday group one suspect who in fact was interviewed Monday, because he learned of his rights before his interview in a telephone conversation with one of us.
} 
Court came to rely more and more on the proposition that the atmosphere in custodial questioning is to some extent "inherently coercive."

In the Journal's study of the impact of Miranda on interrogations in New Haven, the supposed coercion inherent in questioning by the police was examined. The Project found that in some cases the police consciously applied psychological pressure, but that more often the pressure on an initially unwilling suspect was considerably more subtle (though hardly less successful). Often the pressure consisted of little more than reiteration by a detective of the same questions several times alternated with small talk and appropriate urging. The Project investigators did not talk to suspects immediately after their interrogations, however, and their suggestions and conclusions as to what overcame the suspects' apparent willingness to talk were therefore derived only from observation of the interrogation process. ${ }^{28}$

With the suspects interrogated by the FBI, we had a chance, very shortly after they had been questioned, to ask a group of articulate people their reasons for talking to the agents. It would be unrealistic to generalize widely from such a small and atypical group, of course. Still, the reasons they gave for their decisions to answer some or all of the agents' questions may suggest factors important in other contexts as well.

\section{A. Lack of Real Understanding}

One of the prime reasons why the suspects questioned Monday answered the questions of the agents was that they did not appreciate the reasons for remaining silent. Because, as we have observed above, they lacked knowledge of the legal context of the decisions they faced, they could not make an informed choice whether to exercise their rights, even though they were more or less aware of the literal meaning of the statements on the waiver form. One suspect, presented with the form by the agents, said to them, "I really don't know what I should do in a situation like this because I've never been in a situation such as this -I really don't know." No guidance was forthcoming from the agents. He then asked whether the interrogation was a prelude to an arrest or merely an investigation. When the agents indicated that it was just an

28. Project 1575. Of course, the ordinary criminal suspect may have rensons for talking that would not obtain for suspects such as ours. The Project found that for certain types of crimes, suspects were often quite willing to talk to the police, thinking that their stories would exculpate them. Id. 1572. Some suspects may talk to detectives because they feel they will receive better treatment later in the process or because they fear they' might be charged with additional crimes if they refuse to "cooperate." Id. 1546, 1645 n.71. 
"investigation," he decided to sign the waiver form-basing his decision on a distinction any lawyer would have told him was irrelevant.

It seemed to us that because of their ignorance of the legal significance of the interrogation, the suspects were inclined to see it as a moral rather than a legal confrontation. Some of them told us, for example, that they talked because they had taken their civilly disobedient action openly and freely and saw no reason to conceal it. With "nothing to hide," they saw no reason to appear secretive. Most of those interrogated Monday-as well as many people at the Monday night meetingfeared that silence might be interpreted as backing down, and thus saw talking to the agents as a way to demonstrate the strength of their convictions. Some also felt the urge to proselytize the agents-and to per. suade them of the illegality or immorality of the war. Some hoped to influence the views of the Justice Department through their statements to the agents.

Most of those who were interrogated after the Monday night meeting, when asked if they could reconstruct how they would hive responded to questioning if they had not had the prior explanation of their rights and opportunity to ask questions which the meeting afforded, were confident that they would have answered far more than they did. One, for example, said "Oh, yes. I would have told them any" thing they asked, probably, and would have argued with them and stated my case."

\section{B. Nervousness}

One of the major factors preventing intelligent exercise of rights in the typical interrogation is the fact, as the Miranda Project expressed it, that the suspect "is in a crisis-laden situation." ${ }^{20}$ We have noted above how different the situation of our subjects was-there had been no arrests; interrogations took place in homes or offices. Unlike many of the New Haven suspects, they do not seem to have perceived the interrogation process as one in which cooperation would produce subsequent leniency, and noncooperation would produce harshness. Furthermore, our suspects were of equal or higher social status than their interrogators. Finally, the agents generally were more polite and respectful than the New Haven detectives.

Nevertheless, our subjects were very nervous, on the whole. Almost half of them mentioned spontaneously that they "felt nervous" or "had

29. Project 1613. 
butterflies." The stakes were high and became more immediate by the very fact of interrogation. More important, they were confronting authority directly; as one suspect put it: "Well, it was the FBI, you know." The presence of any sympathetic person whose detached judgment could have been called upon would probably have eased this problem. The FBI agents banked on the effects of nervousness and isolation; they generally tried to conduct these interrogations in private, as we noted above.

Nervousness alone, however, probably did not prevent any of those questioned after Monday from carrying through whatever resolve they had taken. What nervousness did do, we think, was to interfere with the capacity of suspects, including those interrogated after the Mondny meeting, to exercise their powers of judgment in conducting themselves deliberately during their interrogations. One suspect observed: "I was kind of half-way aware from following the Miranda case myself that I had certain rights-but I suppose the immediate presence of the FBI just kind of shakes one up to the point where he doesn't think in very rational terms." This problem was more serious for the pre-Mondaymeeting group, where nervousness combined with ignorance and surprise to produce waivers of rights that were not "intelligently" made.

\section{Psychological Pressures in the Social Situation of an Interrogation}

Most of the little that suspects said to the FBI after Monday probably flowed from their desire to appear courteous and not to offend. The most striking lesson we learned from interviewing the suspects after their interrogation is the point, obvious once noticed, that interrogation is a social situation, and suspects respond according to the normal rules of social interaction in such a situation. For middle-class suspects like ours, it seems that one of the fundamental rules is that one not be unnecessarily rude. Even after the Monday meeting, in which the nature of the interrogator's job-and in particular the fact that it is a job -was discussed, the suspects remained largely unable to treat their encounter as an early stage in a formal, adversary legal process. Instead, they tended to see the interview in personal terms, almost as if they were talking to a new acquaintance. One said to the agents, "I believe I have a legal right not to answer questions, if you don't mind."

The agents were careful not to disrupt the social situation in which the rule of politeness obtained. They were themselves very polite; they assumed an engaging, middle-class manner. In most of the interrogations in which the suspect allowed any conversation at all, the agents 
sought to minimize the formality of the situation. They endeavored to create the atmosphere of a normal human encounter. They seemed anxious to talk in personal terms and to avoid being perceived as abstract "interrogators." They initiated small talk about their job and their families and encouraged the suspects to respond in kind.30 They emphasized that they were only doing their job, did not have any personal feelings against the suspect, and wished they were talking to him in other circumstances. Occasionally the agents overstepped the bounds of strict propriety and went so far as to suggest that they were talking "off the record"--although after Monday no student was so immersed in the social situation as to believe that he could respond "oft the record."

The feeling of being socially obliged to answer some questions was mentioned to us by a sizable number of those questioned after Monday. It had been explained at the meeting that the agents would see the interview as a job, not a social call, and from the comments of many of them in their interviews with us, they absorbed this information quite well. Yet even with that background, many of them reported feeling rude when they repeatedly told the agents that they refused to an. swer. One, for example, finally answered two questions he considered trivial because, "I had come to feel very uncooperative and nasty." Another reported feeling so embarrassed at having answered none of the questions that he felt it "pointless" not to answer a few simple factual questions. A few others succeeded in overcoming this feeling. One of them said, "I must say $I$ find it an uncommon experience to be rude, and I don't want to be rude, but I have nothing to say to you."

The failure of the agents to overcome the determination of the few post-Monday suspects who did not answer any questions was determined by these suspects' ability to seize and maintain the offensive. In most of the interrogations, the agents assumed the offensive from the outset and imposed their format upon the encounter. They would begin asking questions, and in the social situation we have described above, a question demands an answer (Miranda states legal, not social, rules). The suspect is thus in a position of having to decide whether to answer each question. In making each such decision, he is subject to all of the stresses and inca-

30. The following is a sampling of instances mentioned in the interviews: "Cce, I was 28 when I joined the Bureau"; conversation about the Rice football team; " $I$ was once a seminary student myself"; discussed suspect's cat and sculpture in his apartment; display of sympathy for the suspect's high blood pressure; "What do divinity students do when they graduate?"; agent mentions that his wife once attempted to get a job at the college where the suspect is chaplain. 
pacities we have dealt with above, and above all to the disability of ignorance and the pressure of politeness. "Well, I wanted to be polite, and it was very hard to be polite while saying, 'No, I won't answer,' and I thought it was innocuous to give them those details." $\mathrm{He}$ is unlikely to capture control of the situation. ${ }^{31}$ Once the interrogators had seized control and imposed their format, they generally could continue to ask the retreating suspect questions until they decided to end the interview. Although the suspect might refuse to answer a question, or even most of the questions, he almost never simply rose and asked the agents to leave. "I didn't feel I could ask them to get out of my room. I almost felt like I had to talk-say something." With the agents on the offensive, even suspects with a great deal of resistance usually ended up answering some questions, although they would rather not have done so.

On the other hand, if the suspect took the offensive, the agents were fortunate to obtain even his name. Those who took the offensive prevented the agents from ever assuming a questioning role. ${ }^{32}$ One, for example, met them outside his office and simply did not allow them inside. He inquired whether the men were FBI agents and, upon being told they were, stated: "In that case, gentlemen, I have nothing to say to you." Another told them in no uncertain tone, before they even offered him the waiver form, that there was no need for it, because he was going to refuse to answer every question they might ask.

The four or five suspects who managed to assert or to capture the offensive were immune from the disadvantages we have discussed. They were as nervous and as ignorant of their rights as the rest, but they

31. The suspect quoted in the preceding sentence was the sole cxception. He became aware of the impotence of his defensive position toward the end of his interview:

"Do you have your draft card with you now?"

"I'd rather not answer."

They smiled and the one who had been doing most of the questioning began gath. ering up the various pieces of paper he had been referring to. Then one of the agents asked a question about some sculpture in my room. (Perhaps this was an elfort to reopen the conversation, but $I$ took it as an opportunity to reassert some feeling of control. I had been nervous at the beginning of the interrogation, had become calmer in the course of it, and now wanted to see if I could make ticm squirm slightly - without malice, for they had been pleasant in their way.)

"Yes. I just wondered if you enjoyed your work" "Well, I've been at it for more than 20 years. I guess I wouldn't be in it so long if I didn't " "The reason I asked is that, well, as you no doubt know, there's been so much criticism of the FBI." (Susan [his wife], not wanting them to feel bad, she sajs, now started mentioning the Liuzao case, etc) "Well, criticism is what makes the world go round. There's criticism and change. We grow with criticism." "Yes, that's what I always tell my students." (They are now trying to get out from behind the coffee table.)

Then the agents left.

32. None of the suspects interviewed on Monday attempted to take the offensive. 
avoided the necessity of making decisions while under these disabilities. They were as subject to the middle-class taboo on rudeness as the others, but they did not allow any social relationship to develop. They never became subject to all the stresses and temptations of the suspect who must retreat from one refusal to the next. ${ }^{33}$ The defensive-retreaters experienced their interrogations as unpleasant and as failures because they had almost all said things they wished they had not. But those who took the offensive received gratification from their successful control. ${ }^{34}$ One told us that it was "a marvelous feeling to finesse the agents."

\section{Conclusions}

Our interviews reinforce the conclusions of the Miranda Project that the psychological interaction between the interrogator and the suspect in an interrogation is extremely subtle, and the interrogator has most of the advantages. Even when we explained the rights to silence and counsel to a group of very bright and extremely willful people, they felt pressed to answer at least some of the questions put to them by the agents. Absent such a preparatory infusion, the experience of the suspects questioned on Monday confirms the Project's finding that the Miranda warnings are almost wholly ineffective, and this obtains even when the suspect is intelligent, and the interrogation is polite, noncustodial, and at the suspect's home.

We conclude, therefore, that if the high purposes of Miranda are to be effected, the warnings alone are insufficient even in the extremely favorable situation we have discussed. For full achievement of $M i$ randa's values, a suspect needs even more than a sympathetic explanation before his interrogation-he needs a sympathetic advocate during the interrogation. Only in this way will most suspects be able to assert

33. This factor of offensive and defensive roles, and the control they cxcrt upon persons subject to them, is worth some serious study. The Miranda Project observers also witnessed a striking example of the power of the offensive: The suspect, arrested witl an accomplice, had been apprehended on a rooftop, with a kit of burglar tools. As he came through the stationhouse door he told the accomplice to kcep quict, announced to the detectives that he had nothing to say to them, asked for a phone, and promply called his lawyer. The detectives never even attempted to question him. Later the ob. servers learned from the detectives that the man was a notorious professional burglar of many years' experience.

34. The pre-Monday-meeting suspects obtained a different kind of gratification from their illusion that they were communicating their position to the agents. This wis short * lived, however, since they all attended the Monday meeting and came to regret their loquaciousness. 
a measure of control over the situation, overcome inevitable nervousness, and avoid the impact of perceived (but irrelevant) social rules operating in a situation structured and manipulated by a professional interrogator.

\section{JOHN GRIFFrrHSt RICHARD E. AYrEs}

\footnotetext{
$\dagger$ Assistant Professor of Law, Yale University. A.B. 1962, University of California (Berkeley); LL.B. 1965, Yale University.

* Editor, Volume 77 .
} 